by the late Mr. F. H. Melland and presented by Mrs. Jelland. The collection contains some very fine sable and roan antelope heads and is of special interest in that the species represent a transition stage from the southerly types of South Africa to the more northerly forms found in Tanganyika Territory and Kenya Colony. Another interesting gift is the skull of a hippopotamus from Nigeria presented by Mrs. Piper. Purchases include a largo collection of South American mammals from Dutch Guiana, and another from Ecuador. The latter is worthy of special mention since it contains a series representing that most interesting genus of Diproto. dont marsupials, Caenolestes. The Dopartment of Mineralogy has received a series of specimens of Darwin glass from Mit. Darwin, Tasmania, collected and urranged by the late Mr. Hartwell Conder and presented by his widow. Darwin glass is a silica glass. Thousands of tons of it in the form of rounded and rod-like pieces are found over an area of sixty square miles in Tasmania. It is believed that the silica-glass was formed by the heat engendered by the impact of a large meteorite. Some crystals of the rare mineral withamite, a pink variety of epidote, have been presented by Mr. W. G. Myers, who found them at the type locality in Glencoe where the new road has cut through the lavas in which withamite occurs. Good crystals of this mineral are rare. A very large rough crystal of microcline feldspar from Norway has been purchased. This crystal measures about $14 \times 12 \times 10$ inches and weighs about 100 pounds.

\section{Report on Abortion}

THE report of the Inter-Departmental Committee on Abortion, which was appointed by the Minister of Health and the Home Secretary under the chairmanship of Mr. Norman Birkett, K.C., has been issued (H.M. Stationery Office. 2s. 6d. net). In the Majority Report, signed by fourteen members, the question of the prevalence of abortion is first examined. They stress the difficulties entailed in arriving at any estimate; but suggest that the number of abortions occurring annually in England and Wales is between 110,000 and 150,000, of which perhaps forty per cent are criminal. The Committee discusses the existing law, analyses the motives for criminal abortion and the methods employed, and examines proposals for amending the law. It recommends that the law should be clarified so as to make it plain that the induction of abortion is legal when the operation is carried out to save the life, or to prevent impairment of health, of the pregnant woman, but expresses strong opposition on ethical, social and medical grounds to any broad relaxation of the law. It is recommended that therapeutic abortions should be notifiable by the operator to the medical officer of health, and that there should be some restriction on the sale of abortifacient drugs. The majority of members of the Committee are not prepared on general grounds to recommend the unrestricted dissemination of birth control advice by the public health services.

\section{The New Radcliffe Observatory}

IN Occasional Notes Roy. Astro. Soc. (No. 4, March 1939), Dr. H. Knox-Shaw gives a very full description of the work on the erection of the 74-inch reflector at Pretoria, and three plates illustrate various parts of the equipment, the turret, the telescope itself as viewed from the north-east, and also the Newtonian observing carriage and the Coude room. It is satisfactory to know that the pyrex disk for the large mirror has been successfully cast and the figuring will be completed in a few months, after which the mirror will be sent to Pasadena for aluminizing. It will be possible to use the telescope at three foci, Newtonian, Cassegrain and Coudé, the focal length in the first case being 30 feet, and the equivalent focal lengths in the last two being $111 \mathrm{ft}$. and $173 \mathrm{ft}$. respectively. The Newtonian focus will bo used for direct photography and the other two for spectroscopic observation. A two-prism spectrograph for use at the Cassegrain focus is under construction and will soon be ready, and a projection measuring machine and also a microphotometer have been made for the Observatory. It is anticipated that the full programmo of the work will be undertaken early in 1910, and the initial programme will include the determination of the radial velocities of the $O$ and $B$ type stars in the portion of the galaxy beyond the reach of the northern observatories. The object of this research is to corroborate present views on galactic rotation. When opportunities occur, photography of the nebule south of $-40^{\circ}$ declination will be undertaken.

\section{Museums and Children}

THE revival of museum efforts which in Great Britain has followed upon the Miers report, has fortunately included in its sweep attempts to increase facilities for the interest and education of the young. But in this aspect of museum work America undoubtedly leads the way, and overyono interested in juvenile education must bo grateful to Miss Ruth Weston for her impressions of American methods which appear as a supplement in the Museums Journal (39, 93, May 1939). Her first impression is one of the bold conception, enterprise, and general 'aliveness' which have produced such museums. Some are special children's museums housed in their own special buildings, in several instances right away from any other museum. Others form sections of larger museums, with special exhibition and other rooms for juveniles, either as an isolated wing or included within the main building. Sometimes the show galleries are supplemented by club rooms, library rooms, reading rooms, and a lecture theatre, which in Boston Children's Museum can seat more than 500. Loan collections of natural history objects for schools and even for individual child borrowers (as at Brooklyn), loan art collections, recording in colour and in black and white the development of art in different periods and countries (like the 2,000 reproductions at Toronto Art Gallery), have become the order of the day in these progressive museums. Much has been done in some British museams, but 
much more must be accomplished if museums are to play their part in the educational system; and there should be tho less hesitation in transforming some of the now existing severe and aridly didactic galleries into simplified children's galleries, since our observation is that adults enjoy and benefit from the children's exhibits as much as tho children themselves.

\section{The World Power Conference}

THE annual report of the World Power Conference for 1938, prepared by the Central Office of the World Power Conference, 36 Kingsway, London, W.C.2, has just been issued. There was a meeting of the International Executive Council in Vienna during August 29-September 1, attended by more than a thousand persons from thirty-seven different countries. Tho British Council was officially represented by Sir Harold Hartley and J. M. Kennedy. Tho British delegation numbered ninety-three and was nearly double the size of any other visiting delegation. Approximately two hundred papers were presented at the meeting. It is hoped to publish theso papers and the discussions on them this year in tho Transactions of the World Pouer Conference. A new national committee has been formed for Algeria, and there are now forty national committees. In response to an invitation issued and accepted in 1936, the second Chemical Engineering Congress of the World Power Conference will be held in Berlin in 1940. At the same time and place the third Congress on Large Dams will be held. The questions to be discussed have already been fixed. By invitation of the Swiss National Committee a meeting of the International Executive Committee will be held in Zurich shortly.

\section{"Micro-entomology" at Stanford University}

WE have recoived several parts of the journal entitled "Microentomology: Contributions to En. tomology from tho Natural History Museum of Stanford University". This periodical is now in its fourth volume, and it only publishes papers emanating from the Museum just named. The text is from manuscript expressly typed by the Stanford University Press and reproduced by the photolith method. This type of publication has been adopted as a partial solution of the prevailing high costs of printing by monotype and hand-set type. The reproduction has been admirably carried out, but the main factor in the process is the perfect typing of the copy, since the method affords little or no opportunity for errors and corrections. Among the papers published in this journal is a series of articles on the Coccide by G. F. Ferris and collaborators. These are well and clearly illustrated and, in fact, illustrations form the notable feature of this publication, the saving on printing costs allowing for an unusually largo number.

\section{New Seismological Observatory}

IT is learned from Earthquake Notes (10, No. 4, April 1939), published by the Eastern Section of the Seismological Society of America, that a new seismo- logical station is soon to be established at Bogotá, Colombia, South America. It will be at a height of some 2,800 m. above sea-level in the Northern Andes, and will thus be one of the highest in the world. This is made possible by a grant from the Carnegie Corporation of New York to the Jesuit Seismological Association, and the director of the station is J. Emilio Ramírez, S.J., of St. Louis University. The new station will fill a very noticeable gap in the map of seismological observatories, and will supply a definitely seismic area with important observational facilities.

\section{The Lister Institute of Preventive Medicine}

THe annual general meeting of the Lister Institute of Preventive Medicine was held on June 16 when the governing body presented the Institute's forty fifth report. This contains a survey of the Institute's activities, with financial statement and the staff changes, during 1938, and a summary of the research work pursued. Studies on viruses are prominent, and Dr. Eagles has investigated a possible virus factor in the causation of acuto rheumatism. Serological investigations include further work by Dr. Felix on the antigenic structure of the typhoid bacillus and on the standardization of therapeutic anti-typhoid serum, and a study by Dr. Muriel Robertson on the immune reactions in vitro of certain ciliate Protozoa. The nutritional value of buckwheat and its sensitizing action to light has been studied by Dr. Chick, and the results suggest that the nutritive value of the proteins of wheat are inferior to those of buckwheat. The National Collection of Type Cultures of Microorganisms is housed at the Institute, and during the year some 6,300 cultures have been distributed, and many new strains deposited for maintenance.

\section{National Baby Week}

Tre National Baby Week Council (117 Piccadilly, London, W.1) announces that 'National Baby Week' will be celebrated during July 1-7. Propaganda this year will be concentrated on "Fathereraft in the Child Welfare Movement", and the "William Hardt" challenge shield is offered for competition among senior girls in public elementary schools studying infant care. Full particulars may be obtained from the Secretary.

\section{International Exhibition of the Art of Greater India}

The Royal Academy, in collaboration with a number of connoisseurs of Indian art, is arranging to hold in January-March, 1940, an International Exhibition of the Art of the Indian Empire, French Indo-China, Netherlands, India, Burma, Malaya, Siam, Afghanistan, Tibet and Nepal. It is believed that the museums and private collections of those European powers most closely connected with the regions of Indian influence can furnish an exhibition of surprising interest and value, which would servo as a prelude to an exhibition of Indian art, drawn mainly from collections in Asia, to be considered when more settled conditions give a reasonable

(Continued on page 29) 